\title{
Don Juan Wolfganga Amadeusa Mozarta w reżyserskiej interpretacji Lii Rotbaumówny - próba rekonstrukcji
}

DOI: $10.14746 / \mathrm{rfn} .2019 .20 .5$

Przez dwanaście lat (1958-1970) Lia Rotbaumówna pełniła funkcję pierwszego reżysera Opery Wrocławskiej. Stanowisko to specjalnie dla niej stworzył Kazimierz Wiłkomirski (wówczas dyrektor tej instytucji), który po obejrzeniu w Operze Śląskiej Wesołych kumoszek $z$ Windsoru ${ }^{1} \mathrm{w}$ jej reżyserii postanowił zaprosić Rotbaumównę do pracy we Wrocławiu. Już samym wykształceniem oraz doświadczeniem, nie tylko reżyserskim, ale również tanecznym i choreograficznym, wyróżniała się Rotbaumówna na tle reżyserów polskiego teatru operowego lat pięćdziesiątych.

Ukończyła Konserwatorium Warszawskie oraz Szkołę Umuzykalnienia i Tańca Scenicznego Tacjanny i Stanisława Wysockich. Przez kilka lat tańczyła w zespole Teatru Sztuki Tanecznej (przekształconym później w Balet Tacjanny Wysockiej), biorąc udział między innymi w słynnych inscenizacjach Leona Schillera w Teatrze im. Bogusławskiego oraz Teatrze Polskim, a także w Międzynarodowym Konkursie Tańca Scenicznego w Paryżu w 1932 roku². Jednocześnie

1 Zob. K. Wiłkomirski, Wspomnień ciąg dalszy, Kraków 1980, s. 302-303.

2 Krótki biogram na temat życia i twórczości Lii Rotbaumówny sporządziłam na podstawie Słownika biograficznego teatru polskiego oraz autoreferatu reżyserki. Zob. Rotbaumówna Lia, [w:] Słownik biograficzny teatru polskiego, t. III: 1910-2000, Warszawa 2017, s. 288-290. Por. Autoreferat Lii Rotbaumówny, Zakład Narodowy im. Ossolińskich, Dział Rękopisów, sygn. 193/2000/2. pracowała jako choreografka zarówno w tym zespole, jak i w teatrach żydowskich - między innymi w Jung Teater czy Trupie Wileńskiej. W 1934 roku wyjechała do ZSRR i tam studiowała reżyserię w Państwowym Instytucie Sztuki Teatralnej w Moskwie, zapoznając się przy tym z przedstawieniami między innymi Wsiewołoda Meyerholda i Aleksandra Tairowa. Lata wojny spędziła na Uralu wraz z ewakuowanym ze Smoleńska Państwowym Teatrem Dramatycznym, w którym działała w charakterze reżysera oraz choreografa; następnie pełniła te funkcje w Państwowym Teatrze Dramatycznym w Wołogdzie. Do 1956 roku stworzyła w ZSRR dwadzieścia sześć inscenizacji, większość w teatrach muzycznych, takich jak: Teatr Komedii Muzycznej w Swierdłowsku, Teatr Komedii Muzycznej w Omsku, Państwowy Teatr Operetki w Moskwie.

W przywołanych Wesolych kumoszkach $z$ Windso$r u$ - pierwszej inscenizacji zrealizowanej przez Rotbaumównę po powrocie do Polski ${ }^{3}$ - od razu zauważył Wiłkomirski pewną właściwość, która okazała się podstawowym atrybutem jej reżyserskiego stylu, mianowicie silną korelację muzyki i działań scenicznych ${ }^{4}$.

\footnotetext{
3 Premiera miała miejsce w Operze Śląskiej w Bytomiu 1.02.1958 r.

4 Wspominając tę premierę, Kazimierz Wiłkomirski pisał: „Nigdy do tego czasu nie zdarzyło mi się widzieć takidealnego współgrania
} 
Kolejne inscenizacje, a przede wszystkim książka jej autorstwa ${ }^{5}$, pokazały, że w swojej pracy Rotbaumówna potrafiła łączyć również inne, często nie idące ze sobą w parze, aspekty - pogłębioną refleksję teoretyczną na temat wystawianego dzieła z praktyczną umiejętnością oblekania go w kształt sceniczny. W niniejszym artykule, starając się uchwycić te dwa elementy, próbuję zrekonstruować reżyserską interpretację opery Don Juan Mozarta, wystawionej w Operze Wrocławskiej w 1969 roku$^{6}$. Za punkt wyjścia, za Stefanią Skwarczyńską ${ }^{7}$, przyjmuję zarówno dokumenty dzieła, jak i dokumenty pracy, wśród których w tym przypadku znalazły się: program teatralny, fotografie $\mathrm{z}$ przedstawień, wyciąg fortepianowy pełniący funkcję egzemplarza reżyserskiego, opis koncepcji reżyserskiej, recenzje, a także relacje śpiewaków uzyskane przeze mnie podczas przeprowadzonych wywiadów.

\section{NIESKRĘPOWANY ŻYWIOŁ ŻYCIA W ZWIERCIADLE INNYCH POSTACI}

Interpretacja postaci Don Juana, którą Rotbaumówna kreśli w nocie programowej spektaklu, przeciwstawia się stereotypowemu podejściu do słynnego uwodziciela $\mathrm{z}$ Sewilli ${ }^{8}$. Za punkt wyjścia $\mathrm{w}$ poszukiwaniu istoty jego osobowości reżyserka, zgodnie z własną praktyką, przyjęła muzykę - wpierw słuchaną i „odczuwaną", następnie za pomocą partytury czytaną

akcji z muzyką, tak głębokiego wniknięcia w każdy szczegół muzycznej treści opery. Ani śladu szarży, żadnej przesady, komediowy humor w najlepszym gatunku". Zob. K. Wiłkomirski, Wspomnień ciąg dalszy..., op. cit., s. 302.

L. Rotbaumówna, Opera a jej kształt sceniczny. Notatki z warsztatu reżysera, Kraków 1969.

6 Ze względu na to, że wrocławski spektakl został wystawiony jako Don Juan, w niniejszym artykule będę posługiwała się właśnie tym określeniem, a nie oryginalnym - Don Giovanni.

Zob. S. Skwarczyńska, Sprawa dokumentacji widowiska teatralnego, [w:] Wprowadzenie do nauki o teatrze, red. J. Degler, t. 3 : Odbiorcy dzieła teatralnego. Widz. Krytyk. Badacz, Wrocław 1978, s. 546-552.

8 L. Rotbaumówna, $W$ kręgu Don Juana, [w:] Don Juan - program spektaklu, Wrocław 1969, s. 8-15. Tekst ów (w nieznacznie rozszerzonej wersji) znajduje się również w książce Rotbaumówny. W wersji książkowej pojawiają się dodatkowo przykłady nutowe, jednak reżyserka nie poddaje ich głębszej analizie, być może ze względu na to, że postać Don Juana zostaje przywołana jako exemplum dla omówienia problemu aktorskiego - utożsamienia się z postacią z pozoru negatywną. Por. eadem, Opera a jej kształt sceniczny..., op. cit., s. $209-214$. i analizowaną . Właśnie dlatego nie zgodziła się uznać Don Juana za bohatera negatywnego, przesiąkniętego cynizmem rozpustnika, którego tragiczny koniec pozwala po raz kolejny wybrzmieć umoralniającej zasadzie o nieuniknionej karze dla zło czyniących. Takiemu podejściu przeczyć ma sama muzyka tchnąca „takim czarem, jakby sam kompozytor był urzeczony swoim bohaterem"10. Według Rotbaumówny Don Juan to przede wszystkim „żywioł życia”, przepełniony radością i nieustającą żądzą zwyciężania „czarodziej miłości”, który nie tyle kocha, ile jest przez kobiety kochany ${ }^{11}$. Na pytanie o to, jaki jest powód tego wyjątkowego powodzenia, Rotbaumówna odpowiada, że nie chodzi tu bynajmniej o jakąś wyróżniającą się urodę czy wdzięk, ale o szczerą idealizację i pełne zaangażowanie, jakie obiektom swojej krótkotrwałej uwagi zapewnia Don Juan - „Kobieta [...] czuje się nagle cudownie wywyższona i wzniesiona na piedestał, z którym już żal jej się rozstać"12.

Niemal jak dopełnienie tej interpretacji brzmią słowa ze Stadiów erotyki bezpośredniej Sørena Kierkegaarda $^{13}$ - bodaj najsłynniejszego eseju na temat Don Juana. Duński filozof pisał, że „w każdej kobiecie pożąda on [Don Juan - J.R.] całej kobiecości, i na tym polega zmysłowo idealizująca moc, z której pomoca on swoje ofiary zarazem upiększa, rozwija i zdobywa"14. Szczerość intencji, idealizująca siła, a przede wszystkim triumfująca witalność, to określenia, które pojawiają się w pracach obojga autorów ${ }^{15}$. Zwracają oni również uwagę na arię „szampańską" jako muzyczny wyraz charakteru Don Juana. Kierkegaard słyszy w tym fragmencie samowystarczalność w utrzymywaniu i ciągłym odnawianiu życiowej

9 Zob. L. Rotbaumówna, Opera a jej kształt sceniczny..., op. cit., s. 26 .

${ }^{10}$ Zob. eadem, $W$ kregu Don Juana..., op. cit., s. 13.

${ }^{11}$ Ibidem.

12 Ibidem.

${ }^{13}$ Zob. S. Kierkegaard, Stadia erotyki bezpośredniej, czyli erotyka muzyczna, przeł. A. Buchner, „Res Facta” 1970 t. 4.

${ }_{14}$ Zob. ibidem, s. 58.

${ }_{15}$ Trzeba przy tym zaznaczyć, że reżyserce najprawdopodobniej nie były znane pisma duńskiego filozofa. Jego nazwisko nie pojawia się $\mathrm{w}$ nocie programowej w szczegółowym wykazie europejskich twórców kreujących i przetwarzających motyw uwodziciela z Sewilli; na Kierkegaarda nie powołuje się również Rotbaumówna, gdy omawia postać Don Giovanniego w swojej książce. Pierwszy polski przekład eseju Kierkegaarda pojawił się w „Res Facta” dopiero w 1970 roku. 
siły ${ }^{16}$, Rotbaumówna pisze o „zachłannej żądzy radości i zwycięstw” i „dionizyjskim upojeniu” ${ }^{17}$. W każdym ujęciu wydaje się, że właśnie owa żywotność jest najistotniejszą cechą Don Juana, a jest to żywotność na tyle silna i nieskrępowana, że w naturalny sposób promieniuje na inne postaci opery. Kierkegaard nazywa zatem Don Juana "głównym mianownikiem” opery, ponieważ wyłącznie dzięki niemu interesujący stają się inni bohaterowie: „Jego życie jest w nich zarazem aktywnym principium życiowym. Jego namiętność pobudza namiętność innych, odbija się echem ze wszystkich stron i przenika swym brzmieniem wszystko"18.

By tę ideę klarowniej przedstawić, filozof sięga po metaforę układu słonecznego. Oto Don Juan jest jak słońce, którego światło odbija się w innych ciałach niebieskich. Otaczający go bohaterowie są zatem widoczni dzięki niemu i wyłącznie w tej części, która przezeń została naświetlona ${ }^{19}$. Bezsprzecznie jednak główną postacią opery pozostaje Don Juan.

Rotbaumówna również zwraca uwagę na centralne usytuowanie tytułowej postaci, w jej perspektywie partnerzy Don Juana stanowią jednak swego rodzaju lustra odbijające różne oblicza postawy spod znaku viva la libertà. Jak pisze: „Jeśli z muzycznej charakterystyki Don Juana wyłania się pięknoduch [...], to jego zwierciadlane odbicie odczarowuje go w naszych oczach, odsłania odwrotną stronę medalu" ${ }^{20}$.

Zwierciadła są dwa. To, które reprezentują Leporello i Masetto, nazywa Rotbaumówna „zwierciadłem ironii i śmiechu", do postaci Donny Anny i Donny Elwiry przynależy „zwierciadło krzywdy i łez”. W tych kontrastujących ze sobą perspektywach Don Juan jawi się jako postać wieloznaczna, której poszczególne oblicza wzajemnie się wykluczają: „To subtelny poeta - to znów trywialny cynik; to pełen wdzięku galant - to znów brutal bez skrupułów [...] to wspaniałomyślny libertyn - to znów bezwzględny despota" $^{21}$. Jaki więc jest Don Juan? Na to pytanie nie daje Rotbaumówna odpowiedzi, akcentując właśnie ową wielorakość (chciałoby się powiedzieć „płynność”)

\footnotetext{
16 Ibidem, s. 80.

17 Zob. L. Rotbaumówna, Opera a jej kształt sceniczny..., op. cit., s. 13.

18 Zob. S. Kierkegaard, Stadia erotyki..., op. cit., s. 70.

19 Ibidem, s. 73.

${ }^{20}$ L. Rotbaumówna, $W$ kręgu Don Juana..., op. cit., s. 14.

21 Ibidem.
}

postaci Don Juana. Postaci, która zyskuje możliwą do zdefiniowania specyfikę jedynie na krótką chwilę i jedynie wobec kogoś lub czegoś. Dopowiedzeniem dla tej nieco postmodernistycznej interpretacji mogłaby być teza Karola Bergera, który twierdzi, że Don Giovanni nie posiada spójnej osobowości i wcale nie dąży do tego, by takową zyskać - nawet muzycznie raczej przejmuje cechy swoich rozmówców, aniżeli tworzy własny sty $1^{22}$.

Wysnute wnioski doprowadzają autorkę do tezy, jakoby Mozart (Lia Rotbaum, poszukując scenicznego kształtu dla partytury, zawsze starała się zrekonstruować perspektywę kompozytora), olśniony pięknem swego bohatera, otworzył mu przestrzeń dla nieskrępowanego używania pełnej swobody, a jednocześnie, konfrontując go z prawdą innych postaci, zaniepokojony pytał o konsekwencje tak pojmowanej wolności ${ }^{23}$. Don Juan pochodzi zatem $\mathrm{z}$ innego porządku etycznego i to jest największy problem. Jednocześnie ów porządek jest wpisany w jego osobowość tak silnie, że niemożliwe jest wyzbycie się go bez porzucenia samego siebie ${ }^{24}$. Dlatego właśnie ostatni dialog Don Juana z Komandorem brzmi, wedle Rotbaumówny, jak „zderzenie żywiołu z tamą ${ }^{25}$. Posąg Komandora to w końcu nie człowiek powracający z zaświatów, ale symbol moralności opartej na stałych zasadach, które mają za zadanie ochronić „zbiorowość ludzką od kataklizmów zagrażających jej, ilekroć żywioł nadużyje swej swobody"26. W starciu tych dwóch postaw nie ma wygranych. Don Juan nie zostaje przecież pokonany, skoro ginie nieugięty. Jego postawa wywołuje jednak szereg pytań, z których, wedle reżyserki, „na czoło wysuwa się niespodziewanie odwieczny - jakże ludzki - temat odpowiedzialności człowieka wobec człowieka"27.

W przeciwieństwie do Kierkegaarda, Lia Rotbaum widzi zatem w udziale innych bohaterów nie potwierdzenie, ale podważenie piękna i czaru Don Juana. Jej interpretacja stoi również w opozycji do tezy Bergera, który postrzega zabicie Don Giovanniego jako

${ }^{22}$ K. Berger, Bach's Cycle, Mozart's Arrow. An Essay on the Origins of Musical Modernity, Berkeley 2007, s. 252.

23 L. Rotbaumówna, W kregu Don Juana..., op. cit., s. 15

24 Ibidem, s. 14.

25 Ibidem, s. 15.

26 Ibidem.

27 Ibidem. 
stłumienie wstydliwej tajemnicy - akt niezbędny dla lepszego funkcjonowania społeczeństwa ${ }^{28}$. Don Juan przy całej swojej wewnętrznej sprzeczności nie może być wcieleniem idei, siłą czy symbolem. Aby zaakcentować temat odpowiedzialności, który w kontekście całkiem niedawnych wydarzeń marcowych zyskiwał konkretny kontekst, reżyserka pozostaje na płaszczyźnie relacji człowieka wobec człowieka.

\section{DON JUAN W TRZECH OBSADACH}

$\mathrm{Na}$ tę premierę wrocławska publiczność oczekiwała z niecierpliwością. Miała to być pierwsza realizacja Don Juana w powojennym Wrocławiu, gdy tymczasem większość polskich miast posiadających sceny operowe miała już ten „egzamin dojrzałości” zespołu za sobą ${ }^{29}$. Oczekiwania wynikały również z faktu, iż Mozart w ogóle rzadko gościł w Operze Wrocławskiej - przed Don Juanem pojawiło się Wesele Figara (1948) i Cosi fan tutte (1960, również w reżyserii Lii Rotbaum), a Rok Mozartowski uczczono zaledwie młodzieńczą jednoaktówką Bastien i Bastienne (1956), graną razem $z$ baletem skomponowanym do Eine kleine Nachtmusik ${ }^{30}$. Początkowo termin premiery ustalono na jesień 1968 roku, jednak przeniesiono ją na 8 lutego 1969 roku ze względu na prace modernizacyjne, $\mathrm{w}$ tym zamontowanie sceny obrotowej, której wymagała inscenizacja ${ }^{31}$. W rezultacie próby trwały pięć miesięcy, co współgrało akurat ze sposobem pracy Lii Rotbaum, która każdą premierę poprzedzała nadzwyczaj dużą liczbą prób scenicznych, często dodatkowe próby dla solistów urządzając po godzinach pracy we własnym mieszkaniu ${ }^{32}$.

Kierownictwo muzyczne objął Andrzej Jurkiewicz, scenografię stworzył Andrzej Sadowski, chór

${ }^{28}$ Zob. K. Berger, Bach's Cycle..., op. cit., s. 255.

${ }^{29}$ Tak pisał o Don Juanie Wojciech Dzieduszycki. Zob. W. Dzieduszycki, Trąby jerychońskie, „Odra” 1969 nr 98, s. 87.

${ }^{30}$ Zob. K. Dachtera, Opera Wrocławska 1945-1995, Wrocław 1995 , s. 87.

${ }^{31}$ Specyfika tej przebudowy może być ilustracją sposobu, w jaki wówczas funkcjonowały teatry. Wedle zasady „,wszystkie rẹce na pokład", w modernizacji sceny pomagał między innymi Janusz Zipser wówczas czołowy solista Opery Wrocławskiej, który oprócz muzycznego posiadał również wykształcenie inżynierskie. Informacja pochodzi z przeprowadzonego przeze mnie wywiadu z Danutą Paziukówną-Zipser.

${ }^{32}$ Informacja pochodzi z rozmowy ze Stanisławem Jurą. przygotował Radomir Szulc. Premiery były właściwie trzy, ze względu na to, że inscenizację przygotowano $\mathrm{w}$ trzech różnych obsadach, chociaż $\mathrm{w}$ trzeciej pojawiali się również śpiewacy $\mathrm{z}$ dwóch poprzednich ${ }^{33}$.

W wywiadach zapowiadających premierę Lia Rotbaum podkreślała, że odbiorcy, którzy zechcą się wybrać na Don Juana w wykonaniu trzech różnych obsad, w istocie zobaczą trzy różne spektakle. $\mathrm{Z}$ tego względu zalecała wybrać się na wszystkie, by ocenić, który z nich był najlepszy ${ }^{34}$. Przytoczona wypowiedź dopomina się o rozwinięcie, ponieważ nie był to rodzaj reklamowego chwytu, który pomógłby zapełnić miejsca na wszystkich trzech spektaklach. Oczywiste jest, że w samo wydarzenie, jakim jest spektakl teatralny, wpisana jest niepowtarzalność, tym bardziej, gdy poszczególne role kreują różni aktorzy. Lia Rotbaum ujawniła tu jednak ważny aspekt swojego reżyserskiego warsztatu, który polegał na tworzeniu koncepcji postaci w zgodzie z indywidualnymi predyspozycjami psychofizycznymi oraz głosowymi ${ }^{35}$ danego solisty czy solistki. Z tego względu na przykład kontrast między Zerliną w interpretacji Krystyny Czaplarskiej oraz Danuty Paziukówny nie wynikał ze sposobu, w jaki każda z solistek realizowała wskazówki reżyserskie, ale właśnie $\mathrm{z}$ różnorodności owych wskazówek ${ }^{36}$. W wielości obsad odnajdywała reżyserka „szanse wzbogacenia spektaklu o jeszcze jedno spojrzenie na zawarty

${ }^{33}$ W roli Don Juana wystąpili: Janusz Temnicki i Bernard Nowacki (z jakiegoś powodu Tadeusz Prochowski, którego nazwisko widnieje w programie premiery, nie śpiewał), w postać Donny Anny wcieliły sie Zofia Konrad i Maria Tomczak, Don Ottavio to Tadeusz Cimaszewski, Ludwik Mika i Feliks Tarnawski, Leporello - Antoni Bogucki i Piotr Ilkowski, Donna Elwira - Halina Słoniowska, Ludwika Kaczkowska, Komandor - Zygmunt Biliński, Maciej Kański i Wacław Wronecki, Zerlina - Danuta Paziukówna, Krystyna Czaplarska i Danuta Zabłocka, Masetto - Zygmunt Biliński, Stanisław Jura, Maciej Kański.

${ }^{34}$ Przed premiera Don Juana [rozmowa z Lią Rotbaumówną], "Słowo Polskie” 7.02.1969, s. 4.

${ }^{35}$ Przez predyspozycje głosowe Lia Rotbaumówna rozumiała charakterystyczną barwę i tembr głosu danego śpiewaka. Zob. L. Rotbaumówna, Niektóre aspekty wokalno-aktorskiego warsztatu, „Zeszyty Naukowe Akademii Muzycznej we Wrocławiu” $1990 \mathrm{nr}$ 55, s. $133-143$.

${ }^{36}$ W przypadku tej roli Paziukówna w zgodzie ze swoją urodą i typem bycia na scenie eksponowała wdzięk i delikatność. Zarzuciła jej to w recenzji Ewa Kofin, pisząc, że „postać przez nią stworzona wydaje sie raczej panienką z dobrego domu niż wieśniaczką. Autentycznie wiejską Zerlinę przedstawia tu tylko Krystyna Czaplarska". Zob. E. Kofin, Don Juan w trzech obsadach, „Słowo Polskie” 1969 nr 61, s. 3. 
w nim problem" ${ }^{37}$. W dodatku, aby zachować spójność koncepcji, która narodziła się w trakcie indywidualnej pracy z solistami, Lia Rotbaum możliwie wcześnie ustalała obsady (zazwyczaj to ona, nie dyrygent, miała ostatni głos w tej kwestii) i przeprowadzała osobne próby dla każdego zespołu. Również po premierze nie zdarzały się raczej zmiany pomiędzy obsadami, a w przypadku wprowadzania nowego solisty Lia Rotbaum nie opierała się na koncepcji stworzonej dla jego poprzednika, ale po raz kolejny wykonywała tę samą pracę - poszukiwała koncepcji postaci spójnej $\mathrm{z}$ jego indywidualnymi możliwościami.

Ciekawą ilustracją tej zasady może być zdarzenie związane z Damą Pikowa Czajkowskiego, którą Lia Rotbaum reżyserowała w Teatrze Wielkim w Łodzi. Premiera inscenizacji miała miejsce w 1967 roku, a ponad rok później (właśnie w czasie pracy nad Don Juanem) reżyserka otrzymała list od Marii Fołtyn, która pytała o pozwolenie (!) na wejście w rolę Lizy $\mathrm{w}$ zastępstwie innej solistki. Z odpisu odpowiedzi reżyserki wynika, że podczas ustalania obsady Rotbaumówna była przeciwna, by powierzyć tę partię Marii Fołtyn. Swoje zastrzeżenia opisuje w ten sposób:

W moim przeświadczeniu Liza Czajkowskiego to osobowość o wybitnie lirycznej strukturze psychicznej, a jednocześnie dużej sile charakteru i odwadze decyzji [...] Otóż w moim odczuciu Pani wewnętrzna struktura psychiczna, rodzaj temperamentu oraz typ kobiecości predestynują Panią raczej do partii takich jak Tosca, ale nie Liza. Liza jest dziewczyną, w której budzi się kobieta. Pani osobista uroda posiada w sobie fascynującą kobiecość, ale nie dziewczęcość. [...] Chodzi o tzw. fakturę, która w odbiorze publiczności odgrywa częstokroć rolę decydującą; współczesna widownia nie jest skłonna do kompromisu w tym kierunku ${ }^{38}$.

Ze względu na prośbę solistki reżyserka decyduje się jednak na „eksperyment” i szuka jeszcze jednej scenicznej wersji Lizy. Podkreśla jednak, że to ona musi Fołtyn w rolę wprowadzić:

Mój współudział uważam w tym wypadku za niezbędny, gdyż - jak wspomniałam - chodzi o rzecz bardzo trudną,

\footnotetext{
37 Zob. L. Rotbaumówna, Opera a jej ksztalt sceniczny..., op. cit., s. 225.

38 Zob. odpis listu do Marii Fołtyn, Zakład Narodowy im. Ossolińskich, Dział Rękopisów, sygn. 73/98/1.
}

o odnalezienie nowego reżyserskiego aspektu roli [...], aby nie przeczył on jednocześnie muzyczno-dramatycznej koncepcji postaci. Musiałabym również poszukać odpowiedniej charakteryzacji dla Pani i w tej charakteryzacji powinna by Pani była odbywać próby ze mną, abyśmy obie - zarówno Pani jak i ja - zaczęly wchodzić „w nową skórę” postaci³.

Cytaty te ukazują nie tylko rzadko spotykaną w teatrze operowym uwagę, jaką reżyserka przykładała do popremierowych losów swojej inscenizacji ${ }^{40}$, ale również dwa ważne aspekty reżyserskiego warsztatu Rotbaumówny. Po pierwsze - bardzo szybko wprowadzała na próby sceniczne rekwizyty i kostiumy ${ }^{41}$, po drugie - punktem odniesienia wszelkich poszukiwań była dla niej zawsze owa „koncepcja muzyczno-dramatyczna" dzieła. To ta koncepcja, pieczołowicie przygotowywana i przedstawiana zazwyczaj na pierwszej próbie reżyserskiej wszystkim solistom w postaci referatu ${ }^{42}$, wyznaczała ramy, w których można było się poruszać, budując daną postać.

Wyciąg fortepianowy, na którym Lia Rotbaum pracowała, realizując Don Juana ${ }^{43}$, ukazuje szereg skrótów dokonanych (najpewniej w porozumieniu $z$ dyrygentem) $w$ strukturze muzycznej oper $y^{44}$. Przede wszystkim reżyserka zrezygnowała $\mathrm{z}$ finałowego sekstetu, najprawdopodobniej dochodząc do wniosku, że nic on już do dramaturgicznej struktury dzieła nie wnosi. Zdaje się, że dla Lii Rotbaumówny świat bez Don Juana już nie istnieje, a sekstet mógłby osłabić finałowe „zderzenie dwóch postaw moralnych”, w którym krył się podstawowy temat opery ${ }^{45}$. Usunęła

39 Ibidem. Osobliwie brzmi ów cytat w kontekście obecnej praktyki teatrów operowych, która sprowadza pracę reżysera do przygotowania inscenizacji, a w rękach asystentów i dyrektorów pozostawia wznowienia i wprowadzanie zmian obsadowych.

${ }^{40} \mathrm{~W}$ Operze Wrocławskiej bywała na kolejnych przedstawieniach bardzo często, po spektaklu przychodziła za kulisy, by przekazać uwagi artystom. Zob. E. Gomułka, Lia Rotbaumówna - portret reżysera, artysty teatru operowego, praca magisterska napisana pod kierunkiem prof. Zofii Urbanyi-Krasnodębskiej, Akademia Muzyczna im. Karola Lipińskiego we Wrocławiu, Wrocław 1999, s. 114.

41 Ibidem, s. 110

42 Ibidem, s. 106.

43 Wyciąg fortepianowy pełniący funkcję egzemplarza reżyserskiego pochodzi z archiwum domowego Danuty i Janusza Zipserów.

${ }^{44}$ Jednym $\mathrm{z}$ ważniejszych etapów przygotowania do realizacji dzieła było wspólne z dyrygentem opracowanie wszystkich skrótów i zmian w partyturze. Wiłkomirski opisuje ten etap w swoich wspomnieniach. Zob. K. Wiłkomirski, Wspomnień ciąg dalszy, op. cit., s. 303-304.

${ }_{45}$ Zob. L. Rotbaumówna, W kręgu Don Juana..., op. cit., s. 15. 
również powtórzenia w niektórych ansamblach (na przykład w pierwszym duecie Donny Anny i Don Ottavia), a także tercet Protegga il giusto cielo. Można mieć wrażenie, że tym sposobem chciała uniknąć wszelkiego spowolnienia i zastygnięcia dramaturgii. Do ingerencji najbardziej zadziwiających, nawet z perspektywy współczesnej praktyki reżyserskiej, należy zmiana kolejności poszczególnych scen - oto po arii Mi tradi Donny Elwiry następowała od razu aria Crudele? Ah no, mio bene! Donny Anny, a nie duet Don Juana i Leporella na cmentarzu, jak chciał Mozart i Da Ponte. W ten sposób z cmentarza bohaterowie od razu przenosili się do pałacu na wieczerzę, co dzięki scenie obrotowej mogło nastąpić bez przerwy na zmianę dekoracji.

Don Juan został, zgodnie z ówczesną praktyką, wystawiony w polskiej wersji językowej. Skorzystano $\mathrm{z}$ najpopularniejszego $\mathrm{w}$ tym czasie tłumaczenia libretta autorstwa Krystyny Konopackiej i Ludwika René. Wyciąg fortepianowy pełniący funkcję egzemplarza reżyserskiego zdradza poprawki, jakie Rotbaumówna wprowadziła do przekładu. Zazwyczaj są to niewiele znaczące korekty w szyku wyrazów lub zastąpienie wybranych słów ich synonimami. Zdarzają się jednak fragmenty, w których reżyserka zmienia sens tłumaczenia na bliższy wymowie włoskiego tekstu. Za przykład niech posłużą ostatnie słowa, jakie padaja $\mathrm{z}$ usta Komandora - Ah tempo più non vè, które Konopacka i René przełożyli jako „Niech cię osądzi Bóg”. Rotbaumówna proponuje własne tłumaczenie „Nastał więc kary czas”, które, choć wciąż niedosłowne, jest bliższe oryginałowi ${ }^{46}$. Podobnie rzecz ma się w arii Donny Anny w I akcie, gdzie wedle polskiego przekładu pierwszego zdania Or sai chi l'onore rapire a me volse chi fu il traditore kobieta nie wspomina o chęci odebrania jej czci przez Don Juana, a jedynie o „przeszyciu serca” i zabiciu ojca. Rotbaumówna wraca do mniej enigmatycznego „zhańbienia” i „splamienia honoru".

${ }^{46}$ Anna Księżopolska-Maturacka $\mathrm{w}$ tłumaczeniu dokonanym na potrzeby wyświetlania napisów i druku w programie dla Teatru Wielkiego - Opery Narodowej przełożyła ten fragment jako: „Czasu więcej nie ma”. Zob. Don Giovanni [program spektaklu], Warszawa 2002 [brak numeracji stron]. Tymczasem Stanisław Barańczak proponuje w tym miejscu (chyba najtrafniejsze) tłumaczenie: „Upłynął już twój czas". Zob. S. Barańczak, Stanisław Barańczak słucha arcydzieł, Kraków 2016, s. 156.
Taka praktyka, która z dzisiejszej perspektywy postrzegania prawa autorskiego może budzić zastrzeżenia, była w pracy Lii Rotbaumówny dość powszechna. Prawdopodobnie wynikała nie tylko ze staranności, z jaką reżyserka analizowała tekst libretta, ale przede wszystkim ze sposobu, w jaki podchodziła do relacji między słowem a muzyką $\mathrm{w}$ dziele operowym. W swojej książce pisała, że „myśl słowna żyje w nierozerwalnym związku z myślą muzyczną, ponieważ muzyka nie tylko odziewa słowo w dźwięk, nie tylko przekłada tekst słowny na muzyczny, ale jednocześnie tłumaczy, interpretuje go, odsłaniając emocjonalny podtekst słowa" ${ }^{47}$. Konsekwencją błędnego tłumaczenia byłoby odebranie owemu „słowo-dźwiękowi”"48 spójności, a co za tym idzie pominięcie lub przekształcenie kompozytorskiej intencji. Reżyserka, o czym warto wspomnieć, zasiadała w Komisji Oceny Librett i Tłumaczeń przy Ministerstwie Kultury i Sztuki, często w ramach tejże Komisji dokonywała również poprawek w przekładach ${ }^{49}$.

Nie ma pewności, na ile wprowadzone przez nią modyfikacje polskiego przekładu Don Giovanniego zostały zrealizowane przez solistów. W niektórych miejscach proponowana zmiana pojawia się w egzemplarzu reżyserskim jako wariant (nad pierwotnym tekstem, $\mathrm{z}$ adnotacja „oba teksty”), a innym razem tłumaczenie Konopackiej i René jest skreślone. Proponowane przez reżyserke zmiany były jednak niewielkie w stosunku do głoszonej przez nia wolności w poprawianiu słabego tekstu libretta ${ }^{50}$.

${ }^{47}$ Zob. L. Rotbaumówna, Opera a jej kształt sceniczny..., op. cit., s. 27.

${ }^{48}$ Tak nazywała Rotbaumówna owo zjawisko pełniące w operze główną rolę. Zob. ibidem.

${ }^{49}$ Dokonała chociażby korekty przekładu libretta Cosi fan tutte autorstwa Włodzimierza Ormickiego oraz Wiesława Goreckiego. Wprowadzone przez nią zmiany były na tyle znaczące, że Ormicki proponował, by uznać ją za współautorkę. Rotbaumówna jednak uznała, że nie jest to konieczne. Zob. odpis listu do mgra Stanisława Garczyńskiego, Przewodniczącego Komisji Oceny Librett i Tłumaczeń przy Ministerstwie Kultury i Sztuki z 27.04.1960, Zakład Narodowy im. Ossolińskich, Dział rękopisów, sygn.73/98/1. O jej zainteresowaniu literaturą świadczy również fakt, że sama napisała libretto do baletu Adama Świerzyńskiego (z udziałem chóru) Pieśn o tęsknocie, który został wystawiony w Operze Wrocławskiej w 1965 roku. Zob. I. Turska, Przewodnik baletowy, Kraków 1989, s. 252-254.

${ }^{50}$ Zob. L. Rotbaumówna, Opera a jej kształt sceniczny..., op. cit., s. $82-83$. 


\section{MINIMALIZM I FUNKCJONALNOŚĆ SCENOGRAFII \\ ANDRZEJA SADOWSKIEGO}

Scena obrotowa podzielona na swego rodzaju mansjony okazała się kluczowym pomysłem w organizacji przestrzeni scenicznej Don Juana. Dzięki płynnemu przechodzeniu jednej instalacji w kolejną zyskał on strukturę ciągu obrazów zmieniających się, jak na ówczesne warunki, w dość szybkim tempie ${ }^{51}$.

$\mathrm{Z}$ jednej strony pomagało to $\mathrm{w}$ utrzymaniu uwagi widza i nadawało spektaklowi wartki przebieg, z drugiej - potęgowało muzyczne i emocjonalne kontrasty. Jak pisał Dzieduszycki:

Widz-słuchacz nie ma możliwości zrzucenia z siebie nastroju poprzedniej sceny, niejednokrotnie zupełnie odmiennej w klimacie. Komedia staje się w ten sposób pełniejsza, dramat nabiera zwartości, kontrasty stają się ostre i łatwe do zauważenia $^{52}$.

Z dokumentacji przedstawień pozostały jedynie czarno-białe fotografie, dlatego niewiele można powiedzieć o kolorach dekoracji i kostiumów. Z recenzji i wypowiedzi śpiewaków wynika, że scenografia została zachowana w odcieniach szarości - Ewa Kofin pisała wprost o jej „prymitywizmie" $i$,brudno-szarym kolorycie”, który w jej ocenie jest „nieporozumieniem"53. Dzieduszycki używał nieco innych określeń, zwracał uwagę na surowość, kolorystyczną jednolitość, ale i funkcjonalność dekoracji ${ }^{54}$.

Fotografie ukazują wyjątkową prostotę poszczególnych elementów. Są to przede wszystkim ściany z nierównymi otworami drzwiowymi i okiennymi, brama zbudowana $\mathrm{z}$ powyginanych $\mathrm{w}$ różne kształty prętów, proste schody, ławka i żyrandol. W scenie na cmentarzu pojawił się dodatkowo mur z wyrytymi w nim krzyżami oraz posąg Komandora stojący na cokole $\mathrm{z}$ zaczerpniętym $\mathrm{z}$ recytatywu napisem:

\footnotetext{
${ }^{51}$ Jak pisał Dzieduszycki - „akcja opery rozwija się gładko i wartko dzięki zastosowaniu sceny obrotowej, a każdy obraz ma swoje malarskie walory”. Zob. W. Dzieduszycki, Trąby jerychońskie..., op. cit., s. 88 .

${ }_{52}$ Zob. W. Dzieduszycki, Strojny Don Juan w Operze, „Wieczór Wrocławia” 1969 nr 35, s. 8.

53 Zob. E. Kofin, Don Juan..., op. cit., s. 3.

${ }_{54}$ Zob. W. Dzieduszycki, Strojny Don Juan w Operze..., op. cit., s. 8 .
}

„Zabójco bez sumienia zły i zuchwały tu zemsta czeka ciebie". Najbogatszy w dekoracje i rekwizyty okazał się finał II aktu. W centrum sceny stał nakryty obrusem stół z masywnymi, zdobionymi krzesłami, a na nim znajdowały się kielichy, lichtarze, jedzenie.

Minimalistyczne „obrazy” układane przy użyciu tych samych lub podobnych elementów cechowała stylistyczna jednorodność i lekkość. Delikatne konstrukcje złożone $\mathrm{z}$ wyjątkowo cienkich ścian, które, by znów zacytować Kofin, „chwieją się przy byle podmuchu" ${ }^{\prime 2}$, pozostawały raczej tłem, które przypominało o pozorności przedstawianego świata. Intencją Lii Rotbaum oraz Andrzeja Sadowskiego nie było bowiem stworzenie na scenie świata rodem z XVII-wiecznej Hiszpanii. Jak reżyserka zapowiadała $\mathrm{w}$ wywiadzie radiowym:

Wraz z współrealizatorem - Andrzejem Sadowskim [...] zamiast [tworzenia] iluzji miejsca akcji postanowiliśmy się ograniczyć do aluzji do stylu epoki, sygnalizując ten styl i czasy jedynie kostiumem, potraktowanym zresztą też umownie. Dekoracja również jest umowna, podporządkowana jest całkowicie dramatycznemu napięciu akcji ${ }^{56}$.

Zgadzałoby się to ze sposobem, w jaki materiałem operował ów scenograf ${ }^{57}$, u którego „nie było malarskich popisów ani udziwnień i nad formy. Była ogromna dyscyplina, klarowność i czystość w organizowaniu przestrzeni scenicznej" ${ }^{38}$. Sadowski bowiem ponad estetyczne walory scenografii stawiał jej znaczenie, dlatego lubował się w operowaniu znakami, niedopowiedzeniem, teatralną umownością. Uważał, że w pracy scenografa najważniejsze jest myślenie, a bardziej niż tworzenie dobrej scenografii interesowało

55 Zob. E. Kofin, Don Juan..., op. cit., s. 3.

56 Don Juan nad Odra [rozmowa z Lią Rotbaum], Archiwum Polskiego Radia, nośnik AS15488.

57 Don Juan był w pracy Sadowskiego jedną z pierwszych realizacji operowych, w których brał udział. Wcześniej stworzył jedynie scenografię do Opowieści Hoffmanna Offenbacha (1962, Teatr Wielki w Warszawie) i Cyganerii Pucciniego (1967, Teatr Wielki w Warszawie). W swoim dorobku miał natomiast współpracę z reżyserami takimi, jak: Kazimierz Dejmek, Kazimierz Kutz, Wanda Laskowska, Konrad Swinarski. Później na stałe związał się z operą, przez wiele lat pracując z Ryszardem Perytem.

58 J. Kasperska-Sadowska, J. Pless, Andrzej Sadzio Sadowski. Scenograf, Warszawa 2013. 


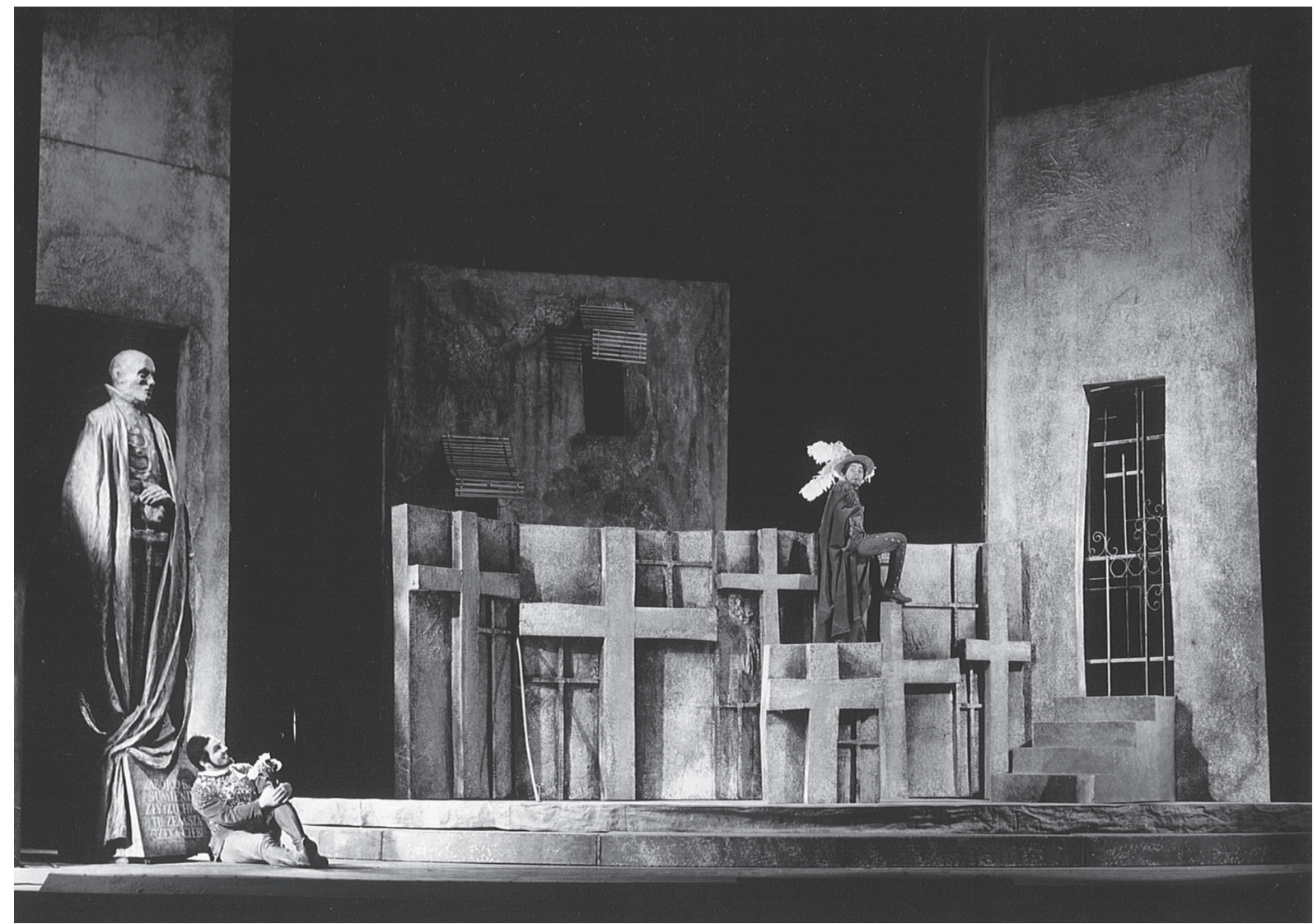

Don Juan - Tadeusz Prochowski, Leporello (przebrany za Don Juana) - Antoni Bogucki. Zdjęcie autorstwa Grażyny Wyszomirskiej. Archiwum Opery Wrocławskiej

go tworzenie dobrego teatru ${ }^{59}$. $Z$ tego powodu dużą wagę przywiązywał do porozumienia $\mathrm{z}$ reżyserem i wspólnego wypracowania koncepcji scenografii, która wobec głównej idei przedstawienia zawsze powinna pełnić służebną funkcję ${ }^{60}$.

W Don Juanie zastosował Sadowski chwyt, który wykorzystał $\mathrm{w}$ realizowanych $\mathrm{w}$ podobnym czasie Powrocie Odysa Stanisława Wyspiańskiego (Lubuski Teatr im. Leona Kruczkowskiego w Zielonej Górze) oraz Ifigenii $w$ Aulidzie Eurypidesa (Teatr im. Juliusza Osterwy w Gorzowie Wielkopolskim) ${ }^{61}$. Polegał on na zachowaniu powściągliwości scenografii przy

${ }^{59}$ Ibidem. Zob. B. Osterloff, Andrzej Sadowski, [w:] Encyklopedia teatru polskiego, http://www.encyklopediateatru.pl/autorzy/2475/ andrzej-sadowski (10.11.2019).

${ }^{60}$ Zob. Kasperska-Sadowska, J. Pless, Andrzej Sadzio Sadowski..., op. cit.

${ }^{61}$ Ibidem. jednoczesnym bogactwie kostiumów. Don Juan ze stereotypową hiszpańską bródką nosi kapelusz z pióropuszem oraz materiałowy kostium zdobiony z przodu błyszczącymi elementami, a w pierwszych scenach występuje $\mathrm{w}$ stroju Zorro $\mathrm{z}$ popularnego wówczas serialu telewizyjnego produkcji Walta Disneya. Zerlina oraz jej przyjaciółki ubrane są w rozkloszowane spódnice z wysokim stanem oraz charakterystyczne welony, Donna Anna i Donna Elwira noszą długie, obszerne suknie i peleryny, bogato wyszywane kamieniami. Recenzenci pisali o "urodziwych"62 kostiumach. „Tak pięknych [...], tak arcybogatych i współdziałających $\mathrm{z}$ aktorami kostiumów nie widzieliśmy jeszcze w naszej Operze"63 - zachwycał się Dzieduszycki, któremu kolorystyczna kompozycja

\footnotetext{
${ }^{62}$ E. Kofin, Don Juan..., op. cit., s. 3.

${ }^{63}$ W. Dzieduszycki, Strojny Don Juan w Operze..., op. cit., s. 8.
} 


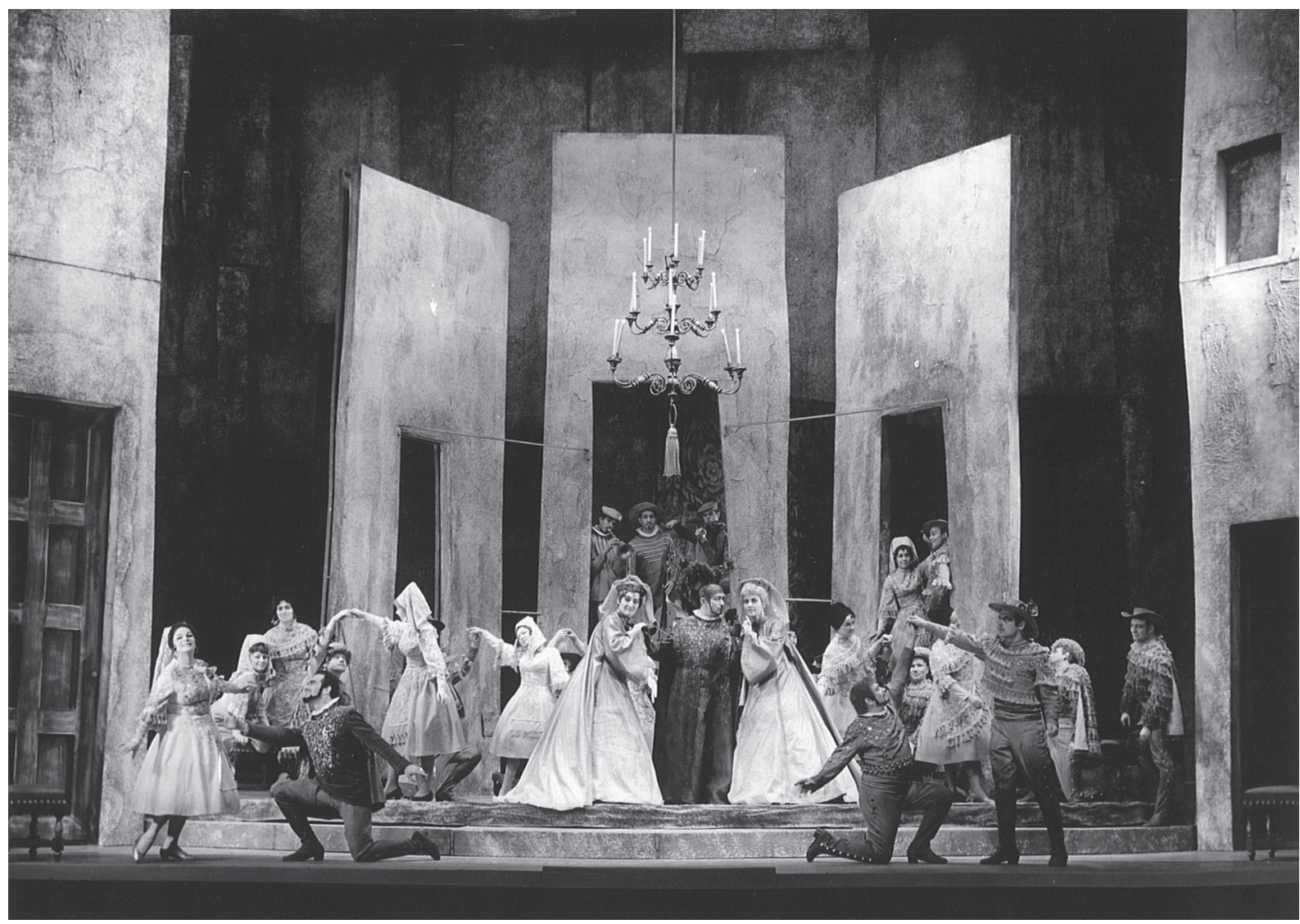

Scena zbiorowa. Zdjęcie autorstwa Grażyny Wyszomirskiej. Archiwum Opery Wrocławskiej

sceny skojarzyła się z malarstwem „słynnych malarzy hiszpańskich" ${ }^{\prime \prime}$.

Nie spodobały się natomiast niektóre szczegóły, jak na przykład posiadanie przez wieśniaków goniących Don Juana karabinów. „Skądże by je wzięli i to tak na poczekaniu?" - pytał w swojej recenzji Józef Kański ${ }^{65}$. Dla Rotbaumówny, której artystycznym credo było „budzenie myśli potrzebnych współczesności”'66, detal ten mógł być jednym ze znaków przypominających o różnych, nie zawsze chlubnych, sposobach zaprowadzania społecznego ładu. Głównej koncepcji podporządkowane zostały również inne rekwizyty. Na pierwszy rzut oka rażący ilustracyjnością katalog

${ }^{64}$ Ibidem.

${ }^{65}$ J. Kański, „Don Juan” we Wrocławiu, „Ruch Muzyczny” 1969 nr 10, s. 12.

${ }^{66}$ Zob. L. Rotbaumówna, Opera a jej kształt sceniczny..., op. cit., zdobyczy Don Juana w formie ogromnego zwoju, na którym nienaturalnie wielkimi cyframi wypisane zostały dokładne liczby kobiet, to groteskowe wyolbrzymienie (a więc ośmieszenie, a może i podanie w wątpliwość) miłosnych dokonań Don Juana. Atrybut ów przynależał do Leporella, a więc zwierciadła, które przez śmiech i ironię miało odbijać postawę głównego bohatera.

Fotografie planu ogólnego ukazują bardzo przemyślaną kompozycję scen zbiorowych, opartą na równowadze $\mathrm{w}$ zapełnianiu przestrzeni scenicznej. Za przykład może posłużyć zachowana na zdjęciu scena z balu u Don Juana. Śpiewacy ustawieni są na trzech poziomach $\mathrm{z}$ niemal idealnym zachowaniem symetrii, której oś wyznacza wiszący na środku żyrandol. Po przeciwnych stronach proscenium widzimy dwie pary (Don Juana adorującego Zerlinę oraz Leporella uspokajającego Masetta). Identycznym 
odbiciem lustrzanym (nawet w szczegółach takich, jak ułożenie palców dłoni) jest pozycja pana i jego sługi. Za nimi, na podwyższeniu, tańczą wieśniacy i wieśniaczki, a z głębi sceny przygrywa im trzech muzyków. W centralnym punkcie znajduje się Don Ottavio w towarzystwie Donny Anny i Donny Elwiry. Symetryczny porządek, wzmocniony jeszcze przez scenografię złożoną z trzech ścian harmonijnie okalających wszystkie postaci, zostaje delikatnie przełamany przez parę chórzystów, którzy nie posiadają swojego lustrzanego odpowiednika.

Mimo precyzyjnego ustawienia całej sceny, obraz ów (bo określenie Dzieduszyckiego jest tu nadzwyczaj trafne) nie jest statyczny. Zatrzymany przez fotografa ruch, spojrzenia, mimika aktorów ujawniają, że mamy tu do czynienia $\mathrm{z}$ wieloma mikrosytuacjami scenicznymi, które do pewnego stopnia zachowują swoją odrębność. Szczególnie zauważalne jest to w kontekście chóru, który nie został potraktowany jako jednolity tłum, ale zindywidualizowane postaci o zróżnicowanych intencjach działania. Niektórzy więc tańczą, prowadząc grę spojrzeń nie tylko ze swoimi partnerami, inni w ustronnym miejscu oddają się flirtom, by kolejni mogli obserwować i komentować dziejące się na ich oczach wydarzenia. Symetryczny układ linearnej kompozycji ma natomiast strzec przed chaosem podkreślać hierarchię poszczególnych „wątków” i akcentować kompozycyjną dominantę $e^{67}$.

\section{NIEUDANA FARSA CZY ZAMIERZONA GROTESKA? O RUCHU SCENICZNYM}

Chcąc choćby pobieżnie określić ruch sceniczny w Don Juanie Rotbaumówny, warto jeszcze na moment wrócić do opisywanej fotografii. W układzie ciał śpiewaków, oprócz symetryczności, zwraca uwage wystudiowana, quasi-taneczna poza. Zerlina z podniesioną dłonią o nienaturalnym (za to przydającym lekkości) układzie palców i zgrabnie wysuniętą stopą stoi właściwie w pozie baletnicy. Delikatność i wdzięk emanujące $\mathrm{z}$ takiego ustawienia kontrastują z gniewem i siłą znajdującego się w lustrzanym odbiciu Masetta (zaciśnięte pięści, napięte mięśnie przy

${ }^{67}$ O zasadach komponowania scenicznego obrazu bardzo szczegółowo pisze Rotbaumówna w swojej książce. Zob. ibidem, s. 111-122. podobnym do Zerliny układzie stóp i dłoni). Obrazek ów to jeden $\mathrm{z}$ wielu przykładów charakterystycznego dla inscenizacji Rotbaumówny sposobu układania choreografii.

Już w recenzjach z Goplany Żeleńskiego - pierwszej opery zrealizowanej przez reżyserkę we Wrocławiu - zwracano uwagę na taneczne ożywienie śpiewaków, a także na silne zespolenie gestu i muzyki. Jak pisała Platówna:

Na scenie nie ma ani jednej tancerki, a jednak sceny zbiorowe są właściwie scenami baletowymi. Wszystkie ewolucje wykonują chórzyści. Wykrzesać z nich tyle elastyczności, tyle temperamentu, tyle życia to naprawdę wielkie osiągnięcie opery [...] Także postacie dramatu: Alina, Balladyna, Grabiec uczestniczą $\mathrm{w}$ tej synchronizacji ruchu $\mathrm{z}$ tłem muzycznym ${ }^{68}$.

Późniejsze inscenizacje pokazały wrocławskiej publiczności, że choreograficzne ożywianie scen zbiorowych to znak rozpoznawczy Rotbaumówny. Wcześniej przekonała się o tym publiczność przedwojennych teatrów żydowskich, takich jak Trupa Wileńska czy Teatr Młodych, w których dwudziestokilkuletnia Lia Rotbaum pełniła funkcję choreografa. Pierwszym miejscem kształcenia reżyserki była bowiem Szkoła Tańca Scenicznego Tacjanny Wysockiej, a pierwszym miejscem pracy - Teatr Sztuki Tanecznej Tacjanny Wysockiej, w którym Rotbaumówna była tancerką, a później również układała choreografię ${ }^{69}$. Stąd najprawdopodobniej potrzeba dokładnego zakomponowania układu ruchu i charakterystyczna „taneczność", którą wprowadzała do swoich operowych inscenizacji.

Dla niektórych śpiewaków stawiane przez reżyserkę wymagania były wysokie, a skrupulatność irytująca, ponieważ Rotbaumówna nie tolerowała na scenie improwizacji i oczekiwała od śpiewaków dokładnego realizowania jej wskazówek ${ }^{70}$. Pytana o to, dlaczego nie pozwala na większą dowolność, odpowiadała, że zdolni aktorsko śpiewacy i tak znajdą dla siebie przestrzeń w zaproponowanych działaniach scenicznych,

${ }^{68}$ S. Platówna, „Goplana” Władysława Żeleńskiego, „Słowo Polskie" 8.04.1959, s. 3.

${ }^{69}$ Zakład Narodowy im. Ossolińskich, Dział Rękopisów, Akc 194/00. Maszynopis ze wspomnieniami Lii Rotbaum.

70 „Trzeba było liczyć kroczki”, jak określił to w rozmowie ze mną Stanisław Jura wykonujący w Don Juanie partię Komandora. 
gdy tymczasem ci mniej zdolni dzięki wiernemu wykonywaniu jej poleceń nie zepsują końcowego efektu ${ }^{71}$. Niekiedy w czasie prób pokazywała również poszczególne gesty, a podłogę sceny zapełniała znakami, które miały pomóc $\mathrm{w}$ realizacji wymaganego ustawienia ${ }^{72}$.

Egzemplarz reżyserski partytury Don Juana pełen jest miniaturowych szkiców, które przedstawiają układ postaci w danej scenie. Stąd wiadomo na przykład, że w arii „katalogowej” ważną rolę pełnił rekwizyt długi zwój, wokół którego rozgrywany był dość bogaty, jak na tak popisowy numer muzyczny, ruch. Często pod danym fragmentem znajdują się rysunki dwóch, a nawet trzech możliwości choreograficznego rozwiązania danej sceny (co potwierdza postulowane zróżnicowanie poszczególnych obsad), a w nutach pojawiają się oznaczenia dokładnego miejsca, w którym ma wystąpić dany gest.

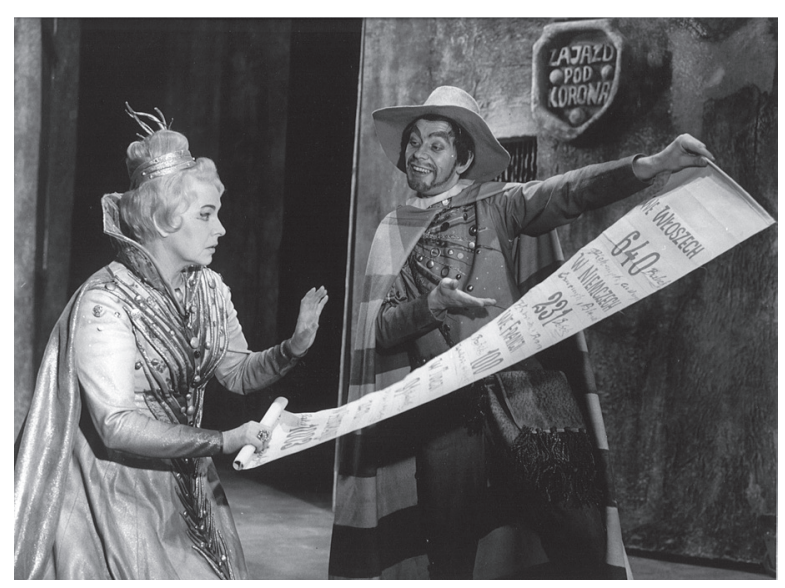

Donna Elwira - Ludwika Kaczkowska, Leporello - Antoni Bogucki. Zdjęcie autorstwa Grażyny Wyszomirskiej. Archiwum Opery Wrocławskiej

Znamienne jest, że $\mathrm{z}$ ewidentnie stylizowanym ruchem, który sam w sobie wywoływał rodzaj „efektu obcości", miała współgrać psychologiczna prawda, oparta na zasadzie możliwie pełnego utożsamienia

\footnotetext{
${ }^{71}$ Informacja pochodzi z wywiadu, który przeprowadziłam z Danutą Paziukówną-Zipser.

${ }^{72}$ Zob. E. Gomułka, Lia Rotbaumówna - portret reżysera, artysty teatru operowego..., op. cit., s. 109.
}

się śpiewaka z postacią ${ }^{73}$. Wedle części recenzentów nie wszystkim solistom udało się w Don Juanie połączyć te dwa, na pozór dość rozbieżne wymagania i oswoić proponowaną choreografię w taki sposób, by przy całej precyzji ruch nie raził swoją nienaturalnością. O „sztuczności ruchu” Marii Tomczak w roli Donny Anny pisała Ewa Kofin, wskazywała również „uderzającą bezczynność [...], a nawet obojętność w kulminacyjnych momentach akcji” Don Ottavia ${ }^{74}$. Ruch i grę aktorską większości śpiewaków skrytykował również Bogdan Jankowski: „wszyscy pozostali wykonawcy [poza Paziukówną i Boguckim - J.R.] poruszali się jak marionetki. Ich poczynania były satyrą na teatr i na operę, tyle że nie była to satyra zabawna. Nużyły bezustanne zmagania $z$ własnymi rękami i nogami, z głosem, z problemami, jakie stawiała partytura”75. Uważał, że „inscenizacja przeładowana jest ruchem", a winę za to, że ruch ów nie jest jednocześnie „życiem”, składał na karb wykonawców $^{76}$. W zupełnie innym tonie wypowiadał się Józef Kański, wedle którego „każda sceniczna postać [...] tchnęła życiem i psychologiczną prawdą" 77 . Odmiennie odczytał również charakterystyczny klimat przedstawienia - wedle Kańskiego udało się Lii Rotbaum „stworzyć i utrzymać [...] swoistą «szekspirowską» atmosferę, w której przejmujący dramat z całkowitą naturalnością co chwila ociera się o gro-

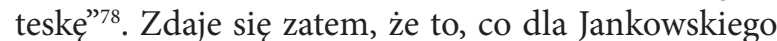
było nieudaną farsą, dla Kańskiego okazało się celowo stworzoną groteską. Interesującym dopełnieniem tych dwóch opinii jest relacja Korwina, który pod względem ruchu i gry aktorskiej zróżnicował szczególnie dwie obsady. W wykonaniu pierwszej „idealna swoboda, trafny gest, wdzięk i świetne wyczucie sytuacji, jak również pyszne sylwetki nasuwają skojarzenia z dobrym teatrem dramatycznym"79. Drugie

73 Zob. L. Rotbaumówna, Opera a jej kształt sceniczny..., op. cit., s. $184-185$.

${ }^{74}$ Zob. E. Kofin, Don Juan..., op. cit., s. 3.

75 Zob. B. Jankowski, Dramat nie bardzo wesoły, „Teatr” 1969 nr 6, s. 12. Warto przy tym zaznaczyć, że recenzent odczytał intencje wyrażoną przez Rotbaumównę w nocie programowej jako chęć lekkiego mówienia o sprawach poważnych, a także zachowania „żartobliwej warstwy przedstawienia”, co, jak wskazuje pierwsza część niniejszego artykułu, nie do końca zgadza się z prawda.

76 Ibidem.

77 Zob. J. Kański, „Don Juan” we Wrocławiu..., op. cit., s. 12.

78 Ibidem, s. 11

79 Zob. Korwin, Don Juan, „Gazeta Robotnicza” 6.03.1969, s. 4. 
przedstawienie to natomiast „mniej ruchu, więcej dostojeństwa i godności, nieco drapieżności i konturu”"80.

\section{ZDERZENIE ŻYWIOŁU Z TAMA - FINAŁ BEZ ROZWIĄZANIA}

Recenzje wskazują na to, że główny bohater nie został odebrany przez krytyków jako pełen niegodziwości libertyn, ale postać wielowymiarowa, pełna wewnętrznych sprzeczności. W jego postawie na przykład Dzieduszycki odnalazł „poszukiwanie treści swojego życia w zupełnej wolności” ${ }^{81}$ oraz „symbol [...] człowieka łamiącego przestarzałe przesądy" ${ }^{82}$. Kluczowy okazał się finał II aktu - o sile jego oddziaływania wspomina większość recenzentów. Nie znalazł się w nim końcowy sekstet, który z jednej strony osłabiłby wydźwięk kluczowego dla reżyserki momentu, z drugiej - podważyłby koncepcję inscenizacyjną, wedle której w starciu dwóch postaw nikt nie odnosi zwycięstwa. W dodatku za pomocą zmiany w kolejności scen reżyserka wyodrębniła i spoiła ze sobą dwa spotkania Don Juana i Komandora. Dokonała tego wbrew koncepcji kompozytora, za to w zgodzie z zamysłem dramaturgicznym, który podpowiadał jej, by nie rozpraszać uwagi arią Donny Anny, gdy zbliża się moment kulminacyjny, wymagający stopniowego budowania napięcia. A ten okazał sie „epilogiem podsumowującym całe dzieło" ${ }^{33}$. Za pomocą silnego skontrastowania dwóch postaci udało się reżyserce zrealizować owo „zderzenie żywiołu z tamą”, o którym pisała w programie. Dzięki użyciu mikrofonu (ukrytego notabene w atrapie długiego miecza), głos Komandora zyskał większą moc oraz metaliczną (a więc nieludzką) barwę, wyraźnie dominującą nad bardzo ludzkim w tym starciu Don Juanem ${ }^{84}$. Również

${ }^{80}$ Ibidem. Trzecie przedstawienie było wedle Korwina „w pewnym sensie powtórzeniem pierwszego", z tą różnicą, że w roli Zerliny i Masetta pojawili się debiutanci - Danuta Zabłocka oraz Stanisław Jura, którzy „na świetnym tle doświadczonych kolegów wypadli zadowalająco".

81 W. Dzieduszycki, Strojny Don Juan w Operze..., op. cit., s. 8.

82 W. Dzieduszycki, Od Halki do Halki, czyli dwadzieścia lat Opery Wrocławskiej, [w:] Opera Wrocławska 1945-1970, red. Adam Dachtera, Kazimierz Koszutski, Tadeusz Riedl, Stanisław Szymański, Wrocław 1970, s. 63.

83 Zob. W. Dzieduszycki, „Don Juan” we Wrocławiu, „Życie Literackie" 6.04.1969, s. 12.

${ }^{84}$ Por. E. Kofin, Don Juan..., op. cit., s. 3. fizyczna wielkość Komandora (stojącego nieruchomo na podwyższeniu) w stosunku do niewielkiej postaci Don Juana oraz gra świateł podkreślała dysproporcję w tej nierównej konfrontacji. Dla pełniejszego opisu tej sceny warto sięgnąć do recenzji Dzieduszyckiego:

Gasną kostiumy, zaciera się tło - w głębokim mroku pojawiają się tylko sylwetki przeciwników: drobna postać Don Juana popierającego swoje wywody gwałtownymi gestami, i wyrastający nad nim nieruchomy, przytłaczający Posąg Komandora ${ }^{85}$.

Ważny jest również fakt, że ów Posąg nie posiada właściwie żadnych cech wspólnych z zabitym na początku opery ojcem Donny Anny. Jest ponadludzkim symbolem wyższej siły, której jednak nie można nazwać boskim wymiarem sprawiedliwości. W ten sposób reżyserka odcina się od jednej z powszechnych interpretacji, wedle której Don Juan, zapraszając Komandora na wieczerzę, zadrwił z boskiego porządku i dlatego musiał ponieść karę. Rotbaumównę interesuje wyłącznie relacja horyzontalna - koncentruje się na stosunku człowieka do człowieka, usuwając Boga także z przekładu libretta.

Szybkie tempo, wartkość akcji, operowanie kontrastem, równowaga i symetria $\mathrm{w}$ komponowaniu przestrzeni scenicznej, a także niejednoznaczność poszczególnych postaci, to najważniejsze cechy Don Juana. Inscenizacja ta okazała się ostatnią realizacją Rotbaumówny na stanowisku pierwszego reżysera Opery Wrocławskiej ${ }^{86}$. Z końcem 1969 roku reżyserka została z pracy zwolniona, otrzymując jednocześnie rentę „z tytułu szczególnych zasług dla PRL”77. Nie wiadomo, w jakim stopniu na decyzję dyrektora Adama Kopycińskiego wpłynęło jej żydowskie pochodzenie. Wiadomo natomiast, że po wydarzeniach

\footnotetext{
${ }^{85}$ Zob. W. Dzieduszycki, „Don Juan” we Wrocławiu..., op. cit., s. 12.

${ }^{86}$ W 1985 roku gościnnie zaproszona wyreżyserowała w Operze Wrocławskiej jeszcze Wesołe kumoszki z Windsoru O. Nicolaia. Zob. K. Dachtera, Opera Wrocławska..., op. cit., s. 271.

${ }^{87} \mathrm{~W}$ kwestii konkretnej daty odejścia reżyserki z etatowej pracy w Operze Wrocławskiej można spotkać się z rozbieżnymi informacjami. W swoim autoreferacie Rotbaumówna pisze o roku 1970, natomiast Słownik biograficzny teatru polskiego podaje dzienną datę 31.08.1969 r. Zdaje się, że najbardziej można ufać aktom osobowym Opery Wrocławskiej, w których widnieje data 31.12.1969 r. Zob. autoreferat Lii Rotbaumówny, op. cit. Por. Rotbaumówna Lia, [w:] Stownik biograficzny teatru polskiego..., op. cit., s. 289.
} 
marcowych 1968 brat Lii - Jakub Rotbaum, z którym mieszkała we Wrocławiu, został pozbawiony możliwości reżyserowania repertuaru innego niż żydowski. Kazimierz Wiłkomirski, z którym Rotbaumówna żyła w głębokiej przyjaźni, w swoich wspomnieniach pisze, że wysłanie reżyserki na rentę stało się wbrew jej woli i nie było podyktowane jakąkolwiek niezdolnością do wykonywania zawodu ${ }^{88}$. Chociaż Don Juan zakończył w Operze Wrocławskiej tzw. erę Rotbaumówny, nie przerwał jej pracy reżyserskiej i pedagogicznej trwającej jeszcze kilkanaście lat ${ }^{89}$.

Inscenizacja, której wybrane elementy starałam się w niniejszym artykule naszkicować, wykorzystując fragmenty pozostałych po niej świadectw, ukazuje nieszablonową interpretację Mozartowskiego dzieła. Ujawnia również niektóre aspekty wypracowanej przez Rotbaumównę metody, w której starała się łączyć wierność partyturze z przekonaniem o artystycznej wolności reżysera. Wpływ Lii Rotbaumówny na polski teatr operowy lat sześćdziesiątych i siedemdziesiątych był znaczący i pozostawił ślad również w późniejszych poszukiwaniach kształconych przez nią artystów. Warto pozostałości po „dziełach, których nie ma" ${ }^{\prime 0}$ odnaleźć, by wydobyć $\mathrm{z}$ zapomnienia zarówno odkrywcze interpretacje, jak i ich autorkę.

\section{BIBLIOGRAFIA}

Barańczak Stanisław, Stanisław Barańczak słucha arcydzieł, Wydawnictwo a5, Kraków 2016.

Berger Karol, Bach's Cycle, Mozart's Arrow. An Essay on the Origins of Musical Modernity, University of California Press, Berkeley 2007.

Dachtera Krystyna, Opera Wrocławska 1945-1995, Państwowa Opera Wrocławska, Wrocław 1995.

Don Juan [program spektaklu], Opera Wrocławska, Wrocław 1969.

Dzieduszycki Wojciech, Don Juan we Wrocławiu, „Życie Literackie" 6.04.1969.

\footnotetext{
${ }^{88}$ Zob. K. Wiłkomirski, Wspomnień ciag dalszy, op. cit., s. 322.

${ }^{89}$ Rotbaumówna prowadziła zajęcia z gry scenicznej na Wydziale Wokalnym Państwowej Wyższej Szkoły Muzycznej we Wrocławiu.

${ }_{90}$ Parafrazuję nietracące na aktualności zdanie Z. Raszewskiego, że „my jedni [teatrolodzy - J.R.] badamy dzieła, których nie ma”. Zob. Z. Raszewski, Dokumentacja przedstawienia teatralnego, [w:] Wprowadzenie do nauki o teatrze, red. J. Degler, t. 3, Wrocław 1976, s. 528.
}

Dzieduszycki Wojciech, Od Halki do Halki, czyli dwadzieścia lat Opery Wrocławskiej, [w:] Opera Wrocławska 1945-1970, red. Adam Dachtera, Kazimierz Koszutski, Tadeusz Riedl, Stanisław Szymański, Opera Wrocławska, Wrocław 1970.

Dzieduszycki Wojciech, Strojny Don Juan w Operze, „Wieczór Wrocławia" 1969 nr 35.

Dzieduszycki Wojciech, Trąby jerychońskie, „Odra” 1969 nr 98.

Gomułka Edyta, Lia Rotbaumówna - portret reżysera, artysty teatru operowego, praca magisterska napisana pod kierunkiem prof. Zofii Urbanyi-Krasnodębskiej, Akademia Muzyczna im. Karola Lipińskiego we Wrocławiu, Wrocław 1999.

Jankowski Bogdan, Dramat nie bardzo wesoly, „Teatr” 1969 nr 6.

Kański Józef, Don Juan we Wrocławiu, „Ruch Muzyczny” 1969 nr 10.

Kański Józef, Don Juan we Wrocławiu, „Trybuna Ludu” 30.05.1969.

Kasperska-Sadowska Joanna, Pless Józef, Andrzej Sadzio Sadowski. Scenograf, Akademia Sztuk Pięknych, Warszawa 2013.

Kierkegaard Søren, Stadia erotyki bezpośredniej, czyli erotyka muzyczna, przeł. Antoni Buchner, „Res Facta” 1970 t. 4.

Kofin Ewa, Don Juan w trzech obsadach, „Słowo Polskie” 1969 nr 61.

Korwin, Don Juan, „Gazeta Robotnicza” 6.03.1969.

Osterloff Barbara, Andrzej Sadowski, [w:] Encyklopedia teatru polskiego, http://www.encyklopediateatru.pl/autorzy/2475 andrzej-sadowski (10.11.2019).

Platówna Stanisława, „Goplana” Władysława Żeleńskiego, „Słowo Polskie” 8.04.1959.

Raszewski Zbigniew, Dokumentacja przedstawienia teatralnego, [w:] Wprowadzenie do nauki o teatrze, red. Janusz Degler, t. 3, Odbiorcy dzieła teatralnego. Widz. Krytyk. Badacz, Uniwersytet Wrocławski, Wrocław 1978, s. 527-543.

Rotbaumówna Lia, [w:] Słownik biograficzny teatru polskiego, t. III, 1910-2000, vol. 2, red. Barbara Berger, Krystyna Büthner-Zawadzka, Grażyna Chmielewska, Anna Jędrzejczyk, Małgorzata Komorowska, Instytut Sztuki Polskiej Akademii Nauk, Warszawa 2017.

Rotbaumówna Lia, Niektóre aspekty wokalno-aktorskiego warsztatu, „Zeszyty Naukowe Akademii Muzycznej we Wrocławiu" $1990 \mathrm{nr} 55$.

Rotbaumówna Lia, Opera a jej kształt sceniczny. Notatki $z$ warsztatu reżysera, Polskie Wydawnictwo Muzyczne, Kraków 1969. 
Rotbaumówna Lia, W kręgu Don Juana, [w:] Don Juan - program spektaklu, Wrocław 1969.

Skwarczyńska Stefania, Sprawa dokumentacji widowiska teatralnego, [w:] Wprowadzenie do nauki o teatrze, red. Janusz Degler, t. 3, Odbiorcy dzieła teatralnego. Widz. Krytyk. Badacz, Uniwersytet Wrocławski, Wrocław 1978, s. $545-552$.

Swolkień Henryk, Trzy wieczory we Wrocławiu, „Kurier Polski” 1969 nr 122.

Wiłkomirski Kazimierz, Wspomnień ciag dalszy, Polskie Wydawnictwo Muzyczne, Kraków 1980.

Zakład Narodowy im. Ossolińskich, Dział Rękopisów, sygn. 193/2000/2; 73/98/1; 194/00.

\section{SUMMARY}

\section{Justyna Rudnicka}

\section{Don Juan by Wolfgang Amadeus Mozart in the directorial interpretation of Lia Rotbaum - an attempt at reconstruction}

Don Juan by Wolfgang Amadeus Mozart, directed by Lia Rotbaum (Opera Wrocławska, 1969), turned out to be an unorthodox staging supported by deep theoretical reflection. This article attempts to reconstruct this staging, on the basis of what is known as the work's documentation (director's copy, photographs, opera programme), reviews, accounts by the singers, as well as the director's theoretical writings. Don Juan in the interpretation of Lia Rotbaum is an ambivalent figure, who combines contradictory attitudes. He is not a thoroughly negative protagonist; it is the other characters in the opera who, like mirrors, reflect other aspects of his activities. For this reason the director makes the question of responsibility of one person towards another the main theme of the work. Directorial techniques include the use of the revolving stage to give tempo and dynamics to individual scenes; removing and changing the sequence of some musical fragments; operating with studied, rich stage movement, and a highly ordered stage design.

\section{Keywords}

Lia Rotbaumówna, Opera Wrocławska, Don Juan, Don Giovanni, Wolfgang Amadeus Mozart, opera theatre 